\title{
SUKSESKAH MAHASISWA BELAJAR ONLINE DI MASA PANDEMI COVID-19?
}

\author{
Nurbaiti \\ Jurusan Teknik Radiodiagnostik dan Radioterapi Poltekkes Kemenkes Jakarta II \\ Corresponden author:nurbaiti.haikal@gmail.com
}

\begin{abstract}
ABSTRAK
Sejak pandemi Covid-19 mahasiswa Poltekkes Kemenkes Jakarta II menghadapi tantangan baru melalui belajar online secara penuh di rumah. Penelitian ini bertujuan untuk memperoleh informasi tentang persepsi mahasiswa tentang proses belajar yang dialaminya. Penelitian dilakukan secara kuantitatif deskriptif melalui survei dengan kuesioner, dikemas dalam googgle-form dan dikirim melalui email. Data dianalisa dengan statistik sederhana. Ada 3,4\% mahasiswa yang sukses belajar online, 39\% merasa tidak nyaman, 20,3\% memiliki kendala internet akses, semua dapat mengakses materi belajar, dan $64,4 \%$ belajar melalui telepon pintar.
\end{abstract}

Kata Kunci: covid-19, belajar online, telepon pintar

\section{PENDAHULUAN}

\subsection{Latar Belakang}

Berjangkitnya penyakit COVID-19 sejak kasus pertama muncul di Wuhan Cina pada bulan Desember 2019 menyebabkan wabah di berbagai negara dengan cepat. Pada tanggal 11 Maret 2020 WHO resmi mengumumkan penyakit COVID19 sebagai pandemi global (Cucinotta \& Vanelli, 2020).

Data penyakit COVID-19 yang dilaporkan pada hari Senin, 27 Juli 2020 di dunia terdapat 16,41 juta kasus dengan kematian sebanyak 652.602, dan di Indonesia kasus positif Covid-19 yang terkonfirmasi bertambah 1.525 orang sehingga total kasus menjadi 100.303, serta jumlah kematian 4.838. Angka ini menempatkan Indonesia pada peringkat 24 pada kelompok negara dengan kasus terkonfirmasi melewati angka 100.000, dengan tingkat kematian 4,8\%. Tingkat kematian ini lebih tinggi dari rerata angka kematian dunia yang berada pada $4 \%$ (Republika, 28 Juli 2020).

Kondisi pandemi memberikan dampak pada berbagai sendi kehidupan masyarakat di seluruh dunia, antara lain di bidang ekonomi, sosial dan pendidikan. Pada bidang pendidikan ada sekitar 421.388 .562 pelajar di seluruh dunia yang tidak lagi bisa mengikuti proses belajar normal. Hampir di seluruh negara yang terdampak Covid-19 sekolah dan universitas ditutup. Upaya ini untuk mencegah 
rantai penularan Covid-19 (UNESCO, 2020). Negara Korea yang sempat membuka sekolah-sekolah di negaranya kembali menutupnya pada hari Jum'at, 25 Mei 2020 setelah jumlah kasus Covid-19 kembali meningkat dan munculnya klaster baru (Republika 29 Mei 2020).

Dunia pendidikan mendapat tantangan yang besar untuk mempertahankan proses belajar siswa dan mahasiswa. Kebijakan bekerja dari rumah atau work from home (WFH) menjadi kebijakan yang diambil oleh banyak negara di dunia (UNESCO, 2020).

Belajar dari rumah atau learning form home (LFH) menjadi fenomena baru yang dijalani oleh komunitas sekolah atau universitas di Indonesia. Berbagai hambatan muncul karena perubahan proses belajar ini. Para orang tua sempat menyampaikan keluhannya kepada Komisis Perlindungan Anak Indonesia (KPAI, 2020a).

\subsection{Tujuan Penelitian}

Mahasiswa di lingkungan Politeknik Kesehatan Kemenkes Jakarta II mengalami kondisi yang kurang lebih sama dengan mahasiswa-mahasiswa lain di masa pandemi Covid-19. Mereka belajar di rumah karena kampus ditutup. Bagaimana persepsi mereka dalam menjalani proses belajar online di rumah dan apakah hambatan yang dialaminya? Pertanyaan inilah menjadi dasar dilakukannya penelitian ini.

\section{STUDI PUSTAKA}

Pandemi Covid-19 dimulai dari kota Wuhan pada bulan Desember 2019. Jumlah kasus bertambah cepat ke berbagai propinsi hingga jumlah kasus terkonfirmasi positif Covid-19 di Cina mencapai 7.736 pada tanggal 30 Januari 2020 (Wu \& McGoogan, 2020). Pada waktu yang bersamaan kasus Covid-19 telah muncul di berbagai negara. Pemerintah negara Jepang, Singapura, Taiwan, Kamboja, Thailand, Malaysia, Filipina, Nepal, Sri Lanka, India, Korea Selatan, Arab Saudi, Australia,kanada, Finlandia, Prancis, dan Jerman telah melaporkan kasus Covid-19 di negaranya (WHO, 2020). Untuk pertama kali di tanggal 2 maret 2020 ada 2 kasus Covid-19 dilaporkan di Indonesia (WHO, 2020). Covid-19 yang disebabkan oleh virus SARS-Cov-2 memiliki pola transmisi dari manusia ke manusia, sehingga proses penularannya cepat (Han \& Yang, 2020).

Mempertimbangkan kondisi penyebaran Covid-19 yang agresif maka pemerintah mengeluarkan kebijakan belajar di rumah bagi seluruh pelajar dan mahasiswa untuk mencegah penyebaran Covid-19. Kebijakan ini dituangkan dalam Surat Edaran Nomor 4 tahun 2020 tentang Pelaksanaan Pendidikan dalam Masa Darurat Coronavirus Diseases (Covid-19) (Kemendikbud, 2020). 
Saat pandemi Covid-19 Pendidikan Jarak Jauh (PJJ) menjadi satu-satunya cara yang dapat dilakukan agar para siswa atau mahasiswa dapat melanjutkan proses belajarnya di rumah. Pandemi Covid-19 yang datang tiba-tiba menyebabkan persiapan pelaksanaan PJJ terbatas dan mendesak. Tidak semua siap menghadapi kondisi ini dengan baik (Febryan A, Rizkyan Adiyudha, Rr Laeny Sulistyawati, 2020).

Peraturan Pemerintah Nomor 66 Tahun 2010 tentang Pengelolaan dan Penyelengaraan Pendidikan dijabarkan dalam Peraturan Menteri Pendidikan dan Kebudayaan Republik Indonesia Nomor 24 Tahun 2012 tentang Penyelenggaraan Pendidikan Jarak Jauh Pada Pendidikan Tinggi (Kemendikbud, 2012). Dalam peraturan tersebut dijelaskan bahwa Pendidikan Jarak Jauh (PJJ) adalah:

a. Pendidikan yang peserta didiknya dan pembelajaranya menggunakan berbagai sumber belajar melalui teknologi infromasi dan komunikasi, dan media lainnya.

b. Pendidikan Jarak Jauh (PJ) merupakan bentuk pendidikan bagi pesera didik yang tidak dapat mengikuti pendidikan tatap muka tanpa mengurangi kualitas pendidikan.

c. Penyelenggaraan PJJ dimaksudkan untuk memperluas dan memeratakan akses pendidikan yang bermutu dan sesuai dengan kebutuhan.

Komisi Perlindungan Anak Indonesia (KPAI) melakukan survei terkait dengan penyelenggaraan PJJ melibatkan 1700 siswa di Indonesia dari tingkat TK sampai SMA atau yang sederajat di 20 propinsi dan 54 kabupaten/kota pada bulan Mei 2020. Datanya menunjukkan ada dua masalah utama dalam pelaksanaan PJJ yaitu tugas belajar yang berat dan beban kuota untuk mengkases internet (KPAI, 2020b). Sebagian mahasiswa terkendala PJJ karena beban biaya untuk memenuhi kuota internet (Firman \& Rahayu, 2020), jaringan yang tidak stabil, dan menimbulkan tugas kuliah yang menumpuk (Jamaluddin et al., 2020). Menteri Nadiem Makarin mengakui bahwa masih banyak kesulitan dalam PJJ karena kondisi setiap di daerah berbeda-beda, terutama internet akses yang belum merata di seluruh Indonesia (Republika, 2020b).

Para pelajar di Jorong Sungai Guntungan, Nagari Pasie Laweh di Kecamatan Palupuah, Kabupaten Agam, Sumatera Barat saat ini mengalami kesulitan mengakses internet dalam proses PJJ. Di daerah itu ada satu lokasi khusus yang memungkinkan koneksi internet yaitu puncak bukit Pakan Salasa. Demikian spesialnya area ini sebagai tempat belajar maka puncak bukit ini terkenal sebagai kelokan HP. Para orang tua rela mengantar anak-anak ke lokasi ini agar bisa belajar online dengan baik. Jorong Sungai Guntungan daerahnya berupa lembah, sungai dan bukit-bukit (Republika, 2020a).

Proses pendidikan jarak jauh (PJJ) adalah proses belajar secara online dengan akses internet menggunakan banyak metode. Umumnya belajar secara 
online dilakukan oleh orang-orang dewasa. Karakteristik orang yang sukses dalam proses belajar online adalah mereka yang memiliki konsep dan keterampilan belajar mandiri, menguasai teknologi pembelajaran online, mempunyai keterampilan komunikasi yang baik, merasakan pentingnya belajar secara interaktif dan kolaboratif, mempunyai kontrol diri untuk fokus pada apa yang dipelajarinya, dan memperlihatkan kebutuhannya untuk berafiliasi atau berhubungan erat dengan orang lain (Dabbagh, 2007).

Proses belajar online pada mahasiswa UIN Sunan Gunung Djati di masa pandemi Covid-19 memperlihatkan bahwa 54,9\% mahasiswa mampu belajar mandiri, 59,8 \% mahasiswa semangat mengikuti belajar online, 63\% menguasai teknologi belajar online, namun 55,1\% memiliki hambatan dalam berkolaborasi dengan teman dan guru dalam proses belajar online. Ternyata Proses belajar online dapat berjalan baik dengan meningkatkan kemampuan komunikasi mahasiswa dan dosen (Hasanah et al., 2020). Komunikasi memudahkan mahasiswa mendapatkan umpan balik dari proses belajar onlinenya (Mather \& Sarkans, 2018).

Perubahan pola dari belajar konventional secara tatap muka menjadi belajar online tidak dapat mengubah pola belajar mahasiswa dalam sekejap. Hal ini sejalan dengan kenyataan bahwa sebelum masa pandemi Covid-19 hanya 23,5\% mahasiswa yang pernah melakukan belajar online (Nursobah, Asep and Dedih, Ujang and Hapid, Hapid and Nurhamzah, 2020).

Pendidikan jarak jauh (PJJ) membutuhkan bahan belajar online yang beragam dan mudah diakses. Bahan belajar ini dapat tersedia di berbagai platform seperti google, google-scholar, youtube, sosial media dan lain-lain. Institusi pendidikan saat ini ada yang sudah mengembangkan modul atau bahan ajar yang secara khusus dikembangkan untuk belajar online mahasiswanya.

Pengalaman Universitas Negeri Surabaya dalam mengembangkan materi belajar online memperlihatkan bahwa agar materi kuliah benar-benar bermanfaat bagi mahasiswa maka mereka perlu dilibatkan dalam mengevaluasinya. Materi kuliah yang dikembangkan dipersiapkan dalam beragam bentuk, mulai dari teks, rekaman suara, visual berupa foto atau gambar, atau video yang bersifat audiovisual. Bentuk materi kuliah yang sangat diminati mahasiswa adalah audiovisual (Rusdiana et al., 2020).

Universitas Peking telah mengembangkan model PJJ dalam bentuk onlinecourse. Sejak terjadi pandemi Covid-19 program belajar online meningkat tajam hingga mencakup 44.700 mahasiswa yang berdiam di rumah atau di asrama (Peking University, 2020). Salah satu unsur penting yang diperhatikan dalam mengembangkan materi belajar online di universitas ini adalah konten belajar disesuaikan dengan tingkat kesiapan akademik dan karakteristik belajar online mahasiswa (Bao, 2020).

Universitas Terbuka Semarang menggunakan metode tutorial webinar (tuweb) sebagai pengganti tutorial tatap muka (TTM) dan didapatkan bahwa $82 \%$ 
mahasiswa mendukung model pembelajaran ini. Mahasiswa yang tidak mendukung umumnya mereka tidak mempunyai perangkat seperti laptop atau komputer, sebagiannya lagi tidak percaya diri untuk mengambil pengalaman baru dalam belajar (Khasanah, Dian Ratu Ayu Uswatun, Hascaryo Pramudibyanto, 2020).

Kemampuan literasi digital merupakan kemampuan untuk memahami dan menggunakan informasi dari berbagai sumber yang sangat banyak yang diakses melalui internet dengan berbagai platform yang tersedia, termasuk sosial media (Paul Casey Medlock, Kerkhoff Shea, 2018). Ketersediaan media belajar secara online atau e-resource erat kaitannya dengan tingkat literasi digital mahasiswa (Nurjanah et al., 2017).

Proses PJJ mahasiswa pada masa pandemi Covid-19 tidak berdampak pada kemampuan literasi digitalnya. Penelitian ini mengevaluasi bagaimana mahasiswa mencari informasi secara digital, mengelola informasi, meningkatkan kreativitas, mengembangkan sikap kritis dan percaya diri. Proses belajar melalui PJJ belum memberikan pengaruh pada 5 (lima) aspek yang diukur dalam penelitian ini (Nursobah, Asep and Dedih, Ujang and Hapid, Hapid and Nurhamzah, 2020).

Ketersediaan fasilitas untuk belajar online dalam proses pendidikan jarak jauh (PJJ) merupakan salah satu indikator yang mendorong keberhasilan pembelajaran jarak jauh (PJJ). Penelitian di Fakultas Keguruan dan Ilmu Pendidikan (FKIP) Universitas Sulawesi Barat (Unsulbar) menunjukkan fakta bahwa hampir semua mahasiswa memiliki telepon pintar (smartphone). Namun banyak mahasiswa yang mendapatkan kesulitan dalam memahami materi pembelajaran secara menyeluruh dan merasa bahwa mereka tetap membutuhkan penjelasan langsung dari dosen, terutama pada materi yang kompleks (Firman \& Rahayu, 2020).

Pada dasarnya mahasiswa memiliki persepsi berbeda terhadap belajar online dan belajar secara langsung melalui tatap muka. Perbedaan tersebut ada pada tantangan, performa belajar, kepuasan dan target capaian belajarnya. Pembelanjaran secara online bagi mahasiswa dirasakan lebih fleksibel, mudah diakses, dan lebih nyaman buat mereka. Belajar secara tatap muka memberikan mereka kesempatan untuk berinteraksi langsung dengan konten pembelajaran dalam kelompoknya dan dosen (Mather \& Sarkans, 2018).

Ada 6 strategi yang dikembangkan dalam pendidikan jarak jauh yang sukses, yaitu: membuat rancangan program belajar darurat untuk mengantisipasi proses belajar yang memburuk; membagi konten belajar dalam beberapa subbagian yang lebih kecil; menekankan penggunaan suara yang lebih kuat tapi lebih lambat dalam penyampaian materi; menggunakan asisten untuk membantu proses belajar mahasiswa; menguatkan kemampuan belajar aktif mahasiswa; mengkombinasikan pola belajar mandiri secara online dan offline (Bao, 2020).

Generasi $X$ yang hidup di tengah berkembangnya teknologi virtual dan internet saat ini memiliki gaya hidup yang dekat dengan internet akses. Mereka 
menggunakan web untuk informasi, termasuk informasi entertainment (Chittenden \& Rettie, 2003).

Penelitian yang dilakukan the Pew Internet dan American Life Project pada tahun 2015 menyebutkan bahwa dua pertiga penduduk dewasa di Amerika Serikat memiliki telepon pintar. Sebagian besar pengguna telepon pintar menggunakan perangkat ini untuk mengakses sosial media (Amanda, 2015). Di Cina 85,8\% netizen mengakses layanan internet melalui perangkat teknologi seperti mobilephone. Kondisi yang mengkhawatirkan pada anak muda di Cina. Mereka terindikasi mengalami adiksi sosial media (Leong et al., 2019).

Tidak jauh berbeda dengan kondisi di negara Amerika dan Cina, penduduk Indonesia yang menikmati akses internet $64 \%$ atau 175,4 juta orang. Sebanyak 94\% pengguna internet pada golongan usia 16 - 64 tahun dan memiliki telepon pintar. Dalam sehari para pengguna internet ini menggunakan waktunya sebanyak 7 jam 59 menit untuk akses internet, diantaranya selama 3 jam 26 menit berselancar di media sosial (Hootsuite, 2020).

\section{METODOLOGI PENELITIAN}

Penelitian dilakukan secara kuantitatif deksriptif. Proses pengumpulan datanya menggunakan metode survei dengan kuesioner yang dikemas dalam bentuk google-form dan disebarkan kepada para responden melalui email. Data yang tersedia dianalisis dan disimpulkan untuk mendapatkan jawaban dari pertanyaan-pertanyaan penelitian. Analisa data menggunakan statistik sederhana berupa persentase (CRESWELL, 2010).

\section{HASIL DAN PEMBAHASAN}

Responden yang terlibat dalam penelitian ini sebanyak 59 orang. Mereka adalah mahasiswa tingkat III pada Program Studi Teknik Radiodiagnostik dan Radioterapi, Poltekkes Kementerian Kesehatan Jakarta II .

Hasil survei ini memperlihatkan persepsi mahasiswa terhadap proses belajar online di masa pandemi Covid-19 dan kendala yang mereka hadapi. Beberapa hal yang dinilai dari penelitian ini adalah:

a. Tingkat kesuksesan belajar

Mahasiswa menilai bahwa keberhasilan target belajar melalui belajar online, 79,9\% merasa bahwa proses belajar online di rumah biasa saja, 16,9\% merasa tidak sukses, dan hanya 3,4\% merasa sukses.

b. Tingkat kenyamanan belajar

Sebanyak 10,2\% mahasiswa dalam proses belajar online merasa nyaman, $39 \%$ tidak nyaman dan 50,8\% menyatakan biasa saja.

c. Akses internet 
Dalam proses belajar online 20,3\% mahasiswa masih terkendala dengan hubungan internetnya.

d. Akses materi kuliah

Mahasiswa yang selalu mengakses materi kuliah secara oline sebanyak $49,8 \%$, mahasiswa yang sering mengakses lewat online 45,8\% dan mahasiswa yang kadang-kadang mengakses via internet sebanyak 8,5\%. Semua mahasiswa mendapatkan materi belajar melalui internet.

e. Perangkat belajar online

Mahasiswa paling sering mengakses internet dalam proses belajar online melalui telepon pintar (64,4\%), perangkat lainnya yaitu laptop (32,2\%) dan sisanya adalah komputer dan tablet. Penggunaan perangkat telepon pintar untuk belajar online sejalan dengan hasil penelitian sebelumnya (Firman \& Rahayu, 2020).

Mahasiswa telah mampu belajar secara online dengan akses internet yang baik, masih ada 20,3\% mahasiswa terkendala internet akses. Namun diantara mereka hanya 3,4\% yang merasa sukses dengan proses belajar onlinenya. Sebagian besar merasa capaian target belajarnya biasa saja. Bagi separuh mahasiswa belajar online dirasakan biasa saja. Ada sebanyak 39\% mahasiswa merasa tidak nyaman dengan metode belajar ini.

Proses belajar secara online pada tahun 2019 telah diperkenalkan kepada mahasiswa Poltekkes Kemenkes Jakarta II dalam bentuk kombinasi dari belajar di kelas secara tatap muka dan belajar melalui media belajar online. Program belajar ini diselenggrakan untuk beberapa mata kuliah. Evaluasi program belajar ini belum dilakukan, sehingga tidak dapat diketahui hasilnya dan manfaatnya bagi mahasiswa.

Proses PJJ dilakukan pada pada semester sebelumnya dengan materi belajar dalam bentuk text dan video. Bahan belajar disimpan dalam sistem vilep, web dan youtube. Sistem Vilep adalah portal belajar online bagi sivitas akademika di Poltekkes Kementerian Kesehatan Jakarta II yang dapat diakses melalui komputer, laptop telepon pintar, atau tablet (PJK2, 2020). Sebagai tambahan media WhatsApp-grup digunakan untuk komunikasi antara dosen dan mahasiswa. Materi belajar yang kurang difahami ketika belajar online diperkaya dan dilengkapi pada proses belajar offline atau tatap muka di kelas.

Pandemi Covid-19 mengharuskan semua mahasiswa belajar dari rumah, maka belajar secara onilne kembali dilakukan di semester genap tahun ajaran 2019-2020 ini. Kebijakan belajar di rumah bagi siswa dan mahasiswa sebagai upaya untuk mencegah penyebaran Covid-19 (Kemendikbud, 2012).

Selama belajar online di masa pandemi Covid-19 mahasiswa mampu mengakses materi kuliah dengan mudah, sudah mengetahui cara mengaksesnya dengan perangkat yang mereka miliki, karena kegiatan ini bukan lagi pengalaman 
yang baru. Bedanya adalah bahwa masa pandemi covid-19 ini mereka sepenuhnya belajar secara online. Pengalaman belajar online yang mereka lakukan pada saat pandemi ini bagi separuh mahasiswa tidak dirasakan berbeda. Di sisi lain ada 39\% mahasiswa yang merasakan tidak nyaman dengan pola belajar online. Sekitar 20,3\% mahasiswa memiliki masalah dengan akses internet, yang berpotensi mengganggu perhatian dan kenyamanannya dalam belajar.

Belajar secara online memang berbeda dengan belajar di kelas. Belajar di kelas sangat interaktif, mahasiswa tidak saja mendengar apa yang disampaikan oleh dosen, tetapi intonasi suara, mimik wajah dan bahasa tubuh, turut menguatkan proses pembelajaran. Sebaliknya pada belajar online hanya suara yang berperan penting dalam proses pembelajaran, karena ekspresi wajah dan bahasa tubuh terhambat karena tampilan hanya dinikmati melalui layar di computer, lap top, tablet atau telepon pintar (Wei Bao, 2020).

Sukses belajar secara online membutuhkan strategi yang berbeda dengan belajar di kelas. Belajar online lebih membutuhkan kemandirian. walaupun belajar online dirasakan lebih fleksibel oleh mahasiswa (Meera Mather, 2018). Tidak semua mahasiswa memiliki kesiapan $100 \%$ belajar online, mereka masih membutuhkan pembelajaran dengan interaksi tinggi seperti di kelas.

Belajar online tidak langsung membuat mahasiswa bisa memanfaatkan informasi yang banyak beredar di dunia maya walaupun jumlah informasi yang dapat diakses sangat banyak. Mahasiswa kemungkinan masih berkonsentrasi menggunakan bahan belajar dari sumber yang diberikan oleh dosen. Proses belajar secara online tidak mendorong mahasiswa belajar secara mandiri dengan mengakses sumber-sumber informasi digital, mengelola informasi yang diperoleh, meningkatkan kreativitas dalam belajar, mengembangkan sikap kritis dan percaya diri (Asep, 2020).

Perbaikan pola belajar online tampaknya membutuhkan proses sosialisasi, adaptasi dan pembekalan pada mahasiswa dan dosen untuk mengembangkan pola pendidikan jarak jauh (PJJ) yang optimal. Perbaikan dapat dilakukan mulai dari pengembangan konten materi dan kemasannya dalam bentuk dokumen, suara atau audiovisual hingga format evaluasi belajar yang interaktif. Assessmen terkait materi-materi belajar online yang sesuai dengan kebutuhan dan tingkat akademik mahasiswa juga diperlukan (Bao, 2020).

Materi kuliah yang tersedia di sistem Vilep Poltekkes Kemenkes Jakarta II masih terbatas. Kondisi ini turut berkontribusi pada proses belajar online mahasiswa. Media WhatsApp-grup baru digunakan untuk komunikasi dan informasi kuliah, belum mendukung proses belajar online atau sebagai media evaluasi belajar.

Perangkat belajar online yang paling banyak dilakukan oleh mahasiswa adalah telepon pintar. Perangkat ini sangat populer dimiliki mahasiswa-mahasiswa di Indonesia. Penggunaan telepon pintar memungkinkan untuk mengakses 
pembelajaran secara online, bersosialisasi dan berteman serta menikmati hiburan. Seberapa banyak waktu yang digunakan untuk belajar online dari keseluruhan waktu mereka berselancar di dunia maya melalui telepon pintar? Pertanyaan ini tidak dapat dijawab dalam penelitian ini. Untuk itu pemanfaatan telepon pintar dalam proses belajar online perlu dicermati oleh orang tua dan institusi pendidikan.

Kesadaran mahasiswa tentang urgensi belajar online di masa pandemi Covid-19 perlu diperkuat seiring dengan adanya risiko adiksi dari penggunaan telepon pintar untuk keperluan lainnya, seperti media sosial dan hiburan (Leong et al., 2019).

\section{KESIMPULAN}

Pada masa pandemi Covid-19 terdapat 79,9\% mahasiswa merasa kesuksesan belajar onlinenya biasa saja, 16,9\% merasa tidak sukses dan 3,4\% yang merasa sukses. Ada 39\% mahasiswa yang merasa tidak nyaman dengan pola belajar online, dan 20,3\% mahasiswa masih kesulitan mengakses internet untuk belajar online.

Pola belajar online dalam lingkup pendidikan jarak jauh (PJJ) yang diterapkan secara penuh karena adanya wabah Covid-19 memberi tantangan bagi mahasiswa, dosen dan institusi pendidikan.

Materi belajar online yang terbatas, hambatan akses internet, dan budaya belajar mandiri yang belum terbentuk memberikan kontribusi pada proses belajar online mahasiswa.

\section{DAFTAR PUSTAKA}

Amanda, L. (2015). Teens, Social Media \& Technology Overview 2015 / Pew Research Center. Pew Research Center. https://www.pewresearch.org/internet/2015/04/09/teens-social-mediatechnology-2015/

Bao, W. (2020). <scp>COVID </scp> -19 and online teaching in higher education: A case study of Peking University. Human Behavior and Emerging Technologies, 2(2), 113-115. https://doi.org/10.1002/hbe2.191

Chittenden, L., \& Rettie, R. (2003). An evaluation of e-mail marketing and factors affecting response. Journal of Targeting, Measurement and Analysis for Marketing, 11(3), 203-217. https://doi.org/10.1057/palgrave.jt.5740078

CRESWELL, J. W. . (2010). Research Design : Pendekatan Kualitatif, Kuantitatif, dan Mixed.

Cucinotta, D., \& Vanelli, M. (2020). WHO declares COVID-19 a pandemic. In Acta 
Biomedica (Vol. 91, Issue 1, pp. 157-160). Mattioli 1885.

https://doi.org/10.23750/abm.v91i1.9397

Dabbagh, N. (2007). The online learner: Characteristics and pedagogical implications. In Contemporary Issues in Technology and Teacher Education (Vol. 7, Issue 3).

Febryan A, Rizkyan Adiyudha, Rr Laeny Sulistyawati, A. (2020). Catatan Kesemrawutan PJJ, dari Guru hingga Fasilitas / Republika Online. Republika. https://republika.co.id/berita/qdrrgu328/catatan-kesemrawutan-pjj-dari-guruhingga-fasilitas

Firman, F., \& Rahayu, S. (2020). Pembelajaran Online di Tengah Pandemi Covid-19. Indonesian Journal of Educational Science (IJES), 2(2), 81-89. https://doi.org/10.31605/ijes.v2i2.659

Han, Y., \& Yang, H. (2020). The transmission and diagnosis of 2019 novel coronavirus infection disease (COVID-19): A Chinese perspective. Journal of Medical Virology, 92(6), 639-644. https://doi.org/10.1002/jmv.25749

Hasanah, A., Lestari, A. S., Rahman, A. Y., \& Daniel, Y. I. (2020). Analisis aktivitas belajar daring mahasiswa pada pandemi Covid-19. Digilib Uinsgd.

Hootsuite. (2020). Digital 2020: Indonesia - DataReportal - Global Digital Insights. Hootsuite. https://datareportal.com/reports/digital-2020-indonesia

Jamaluddin, D., Ratnasih, T., Gunawan, H., Paujiah, E., Pai, J., Gunung, S., \& Bandung, D. (2020). Pembelajaran Daring Masa Pandemik Covid-19 Pada Calon Guru: Hambatan, Solusi Dan Proyeksi.

Kemendikbud. (2012). Dasar Hukum - Pendidikan Jarak Jauh (PJJ). Kemendikbud. https://pjj.pens.ac.id/index.php/dasar-hukum/

Kemendikbud. (2020). Kementerian Pendidikan dan Kebudayaan » Republik Indonesia. Kemendikbud. https://www.kemdikbud.go.id/main/blog/2020/03/se-mendikbudpelaksanaan-kebijakan-pendidikan-dalam-masa-darurat-penyebaran-covid 19

Khasanah, Dian Ratu Ayu Uswatun, Hascaryo Pramudibyanto, B. W. (2020). Pendidikan Dalam Masa Pandemi Covid-19 / Jurnal Sinestesia. Sinestesia. https://sinestesia.pustaka.my.id/journal/article/view/44

KPAI. (2020a). Ada 246 Aduan di KPAI soal Belajar Daring, Siswa Keluhkan Tugas 
Menumpuk-Kuota / Komisi Perlindungan Anak Indonesia (KPAI). KPAI. https://www.kpai.go.id/berita/ada-246-aduan-di-kpai-soal-belajar-daringsiswa-keluhkan-tugas-menumpuk-kuota

KPAI. (2020b). Survei KPAI: Mayoritas Siswa tak Senang Pembelajaran Jarak Jauh. KPAI. https://mediaindonesia.com/read/detail/307985-survei-kpai-mayoritassiswa-tak-senang-pembelajaran-jarak-jauh

Leong, L. Y., Hew, T. S., Ooi, K. B., Lee, V. H., \& Hew, J. J. (2019). A hybrid SEMneural network analysis of social media addiction. Expert Systems with Applications, 133, 296-316. https://doi.org/10.1016/j.eswa.2019.05.024

Mather, M., \& Sarkans, A. (2018). Student Perceptions of Online and Face-to-Face Learning conditions of the Creative Commons Attribution license (CC BY-NCND). In International Journal of Curriculum and Instruction (Vol. 10, Issue 2).

Nurjanah, E., Rusmana, A., \& Yanto, A. (2017). Hubungan Literasi Digital dengan Kualitas Penggunaan E-Resources. Lentera Pustaka: Jurnal Kajian Ilmu Perpustakaan, Informasi Dan Kearsipan, 3(2), 117. https://doi.org/10.14710/lenpust.v3i2.16737

Nursobah, Asep and Dedih, Ujang and Hapid, Hapid and Nurhamzah, N. (2020). Dampak pembelajaran daring terhadap penguatan literasi informasi dalam budaya akademik mahasiswa - Digital Library UIN Sunan Gunung Djati Bandung. Digilib Uinsgd. http://digilib.uinsgd.ac.id/30701/

Paul Casey Medlock, Kerkhoff Shea, S. H. (2018). ResearchGate. IGI Global. https://www.researchgate.net/publication/318508429_Digital_Literacy_for_the_ 21st_Century/link/596e7135aca272d552fe3b3c/download

Peking University. (2020). Fighting COVID-19: Peking University strengthens online communication with global universities_Peking University. Peking University. http://newsen.pku.edu.cn/news_events/news/global/9686.htm

PJK2. (2020). Virtual Learning Poltekkes Kemenkes - vilep-pusdik. PJK2. http://vilep-poltekes.kemkes.go.id/

Republika. (2020a). Demi Belajar Daring, Siswa Palupuah Berburu Sinyal ke Bukit / Republika Online. Republika. https://republika.co.id/berita/qe050c384/demibelajar-daring-siswa-palupuah-berburu-sinyal-ke-bukit

Republika. (2020b). Mendikbud: Kuota Internet Jadi Masalah Utama PJJ / Republika 
Online. Republika. https://republika.co.id/berita/qea698354/mendikbudkuota-internet-jadi-masalah-utama-pjj

Rusdiana, E., Rusdiana, E., \& Nugroho, A. (2020). Respon Mahasiswa Pada Pembelajaran Daring Bagi Mahasiswa Mata Kuliah Pengantar Hukum Indonesia UNESA. Integralistik, 31(1), 1-12. https://doi.org/10.15294/integralistik.v31i1.21834

UNESCO. (2020). COVID-19 Educational Disruption and Response. UNESCO. https://en.unesco.org/news/covid-19-educational-disruption-and-response WHO. (2020). TECHNICAL FOCUS: Laboratory detection.

Wu, Z., \& McGoogan, J. M. (2020). Characteristics of and Important Lessons from the Coronavirus Disease 2019 (COVID-19) Outbreak in China: Summary of a Report of 72314 Cases from the Chinese Center for Disease Control and Prevention. In JAMA - Journal of the American Medical Association (Vol. 323, Issue 13, pp. 1239-1242). American Medical Association.

https://doi.org/10.1001/jama.2020.2648 